\title{
THE IMPACTS OF MULTIPLE LIGHTSHELVES ON NATURAL LIGHTING DISTRIBUTION AND EFFECTIVE TEMPERATURE AT OFFICE ROOMS
}

\author{
Eddy INDARTO ${ }^{a}$, Gagoek HARDIMAN ${ }^{a}$, Wahyu Setia BUDI ${ }^{b}$, Djalal Er RIYANTO ${ }^{b}$ \\ ${ }^{a}$ Department of Architecture, Faculty of Engineering, Diponegoro University, Semarang, Indonesia \\ ${ }^{b}$ Department of Physics, Faculty of Mathematics and Science, Diponegoro University, Semarang, Indonesia \\ E-mail:eddy.indarto@gmail.com (corresponding author)
}

Received 29 August 2017; accepted 12 October 2017

\begin{abstract}
Daylighting with light-shelf is not a simple strategy. Therefore, this research aims to investigate how far the application of light-shelf can block direct sunlight and how much the distribution of daylight at office rooms is produced.

This research is a simulation using EnergyPlus from OpenStudio. Data as measurement results collected from on-site research were used as the validation base of the simulations both with multiple light shelves and without multiple light shelves.

The building orientation is toward north east (azimuth $51^{\circ}$ ), and the result showed that using multiple light shelves on the building was able to distribute evenly the intensity of natural lighting into the rooms. On the edge of the windows, there has been change of the light intensity which was previously too bright (from 925 Lux at 5 p.m. for the lowest and 7200 Lux at 9 a.m. for the highest; to 460 Lux at 5 p.m. for the lowest and 1400 Lux at 12.00 p.m. for the highest). Besides, the use of multiple light shelves was also able to lower the room temperature particularly at rush hours starting from $9.00 \mathrm{a} . \mathrm{m}$. to $3.00 \mathrm{p} . \mathrm{m}$. where the biggest difference of the temperature occurred at $3.00 \mathrm{p} . \mathrm{m}$. (between $29.1^{\circ} \mathrm{C}$ and $28.4^{\circ} \mathrm{C}$ in which the temperature decreased $0.7^{\circ} \mathrm{C}$ ). These aforementioned facts have given contribution to the efficiency of energy used in $\mathrm{AC}$ while the main benefit of this research is developing knowledge about daylighting in architectural design particularly in passive design method.
\end{abstract}

Keywords: daylighting and decreasing room temperature.

\section{Introduction}

Designing ecological architecture must put the orientation and refers to macro cosmos principals. (Heinz 2008) revealed that tropical architecture is architecture for the tropical areas and architectural designs considering tropical climate ecology. Based on this fact, tropical architecture design can be achieved by considering sub-purposes of energy-efficient development which includes:

a. Efficiency in un renewable energy sources;

b. Efficiency in un renewable building material sources;

c. Efficiency in natural resources;

d. Efficiency in building products.

In relation to energy-efficient efforts as a process of energy conservation, (Smith 2005) stated that building design must be able to prevent the solar radiation in order to obtain sufficient thermal balance and to achieve visual comfort, so it must be able to optimally allow natural lighting. Therefore, "Passive Design" is one of the ways to achieve this goal.
Energy conservation is actually not a new criterion in architectural design. Context of a building existence is always determined by climatic limits and building materials. Throughout the history, climates, energy, and resource needs are fundamental points in arts and architectural designs. The condition of tropical areas do not prevent designers to create elegant architecture works as solutions to avoid negative features of tropical climate such as heat and humidity and to utilize sunlight, as one of its benefits, that shines throughout the year as natural light in rooms. With relation to the explanation, Egan (1983) and Rüdiger, Hofmann (1992) also stated that the good use of natural light can reduce the use of electricity for lighting. Besides, it is also related that the good natural daylighting can reduce the use of electricity for lighting through various natural light control strategies (Steffy 2002) also revealed that there is a contradiction in the overcoming problem in tropical areas. On the one hand, windows are needed to bring the sunlight as a natural lighting in daylight; 
but on the other hand, windows also bring heat from the sunlight into room.

In order to avoid/block sunlight which brings heat, it can be done by using sun-shading device. However, the use of sun-shading device has a risk in decreasing natural light intensity that comes into the room. Furthermore, Liebard, de Herde 2004) stated that it is important to apply the natural light strategy which aims to design the utilization of natural light in order to allow the light to enter into a building both dispersed and focused as needed; and also which is able to block direct sunlight that brings heat.

One of the ways to utilize natural light that many times has been done is applying "daylighting" strategy on a building. Szokolay 2008) also stated that in general there are two mostly applied daylighting strategies, they are:

a. Classic Daylighting Strategy that consists of:

1. Light shelf that relies on the field reflector to obtain natural light.

2. Reflector that relies on the mirror reflector.

b. Technological Daylighting Strategy. This strategy uses many active reflectors which can search for the incoming sunlight automatically. It is known as "Heliostat".

In the area of Diponegoro University, Semarang, the architectural design of new buildings uses light shelf as the classic daylighting strategy. Furthermore, it is very interesting to make a research with the title "The Impacts of Using Multiple Light Shelves on Natural Lighting Distribution and Effective Temperature at Office Rooms".

\section{Methods}

\section{Astronomical location and building orientation}

This office building, astronomically located at 6.40 degrees northern latitude, $110,312^{\circ} 110.3120$ East Longitude, and Time Zone $=\mathrm{GMT}+7$.

While the windows orientation of the office as the research site forms an angle $51^{\circ}$ (clockwise) from the north. (Fig. 1).

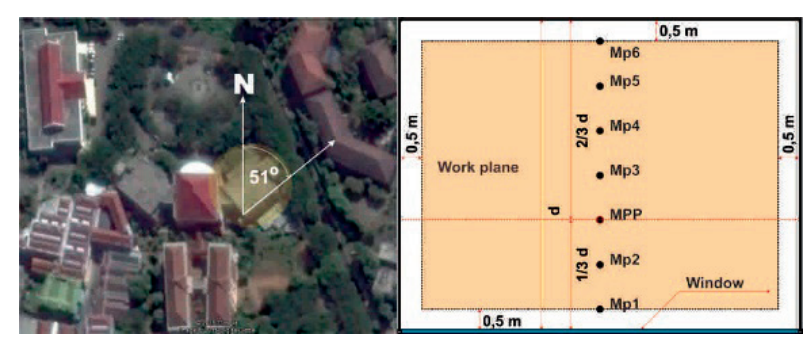

Fig. 1. Windows orientation and measurement point in an office room
The measurement position of both field measurement and Energy+ measurement were done in 7 (seven) points, namely Main Measurement Point (MMP) located in the working plane, in the middle adjacent to apertures, and located at $1 / 3$ of a distance between aperture areas and the wall behind it. To know the distribution of light intensity, especially light distribution starting from the apertures into the room (avoiding the apertures), Measurement Points (MP) were established; namely MP1 and MP2 whose position from MPP are close to the apertures and MP3, MP4, MP5 and MP6 whose position from MPP are far from the apertures as seen in Figure 1.

\section{Building data}

Technically the data were related to the plan and the detailed piece showing the position of multiple lights shelves and were redrawn using ScketsUp for Energy+ simulation in the lecturers' room as the object of the study can be seen in Figure 2 .

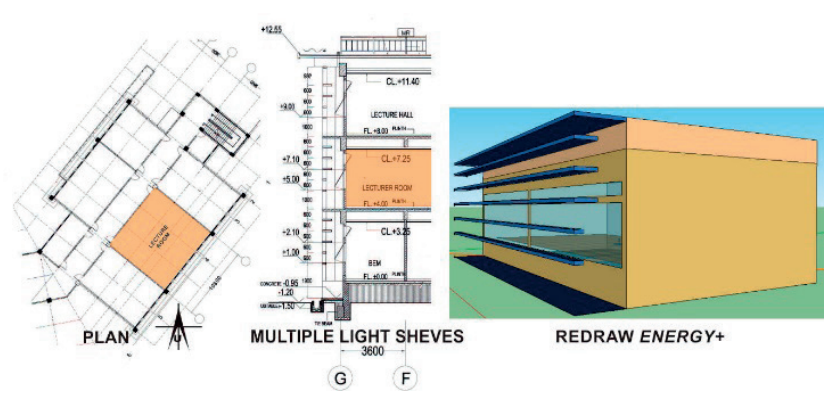

Fig. 2. Redraw for Energy+ Simulation

Source: taken from the existing picture.

\section{Daylighting}

Gretz 2002) stated that light takes infinite and various ways to reach a certain point. Interior Daylighting consists of three components (Fig. 3).

In addition, based on the research done by (Huddleston 2012), in a room with the condition as shown in Figure 4 at left side, it showed that the actual effective area of glass field was above $0.9 \mathrm{~m}$ from the floor, multiplied with windows panel transmission (for example 0.8 for double glazing). The effective window's height is the window area which is divided by the width. This condition is possible if the effective window area is $0.9 \mathrm{~m}$ above the floor, wider than $1 / 6$ of total field area. In the case of two or more windows in one field, an effective window's height will be counted from effective total window area divided by the width.

Furthermore, the grouping of the high level lighting area can purely use daylighting. Whereas medium lighting level can still use the natural lighting, it must be combined with artificial lighting. In the furthest 


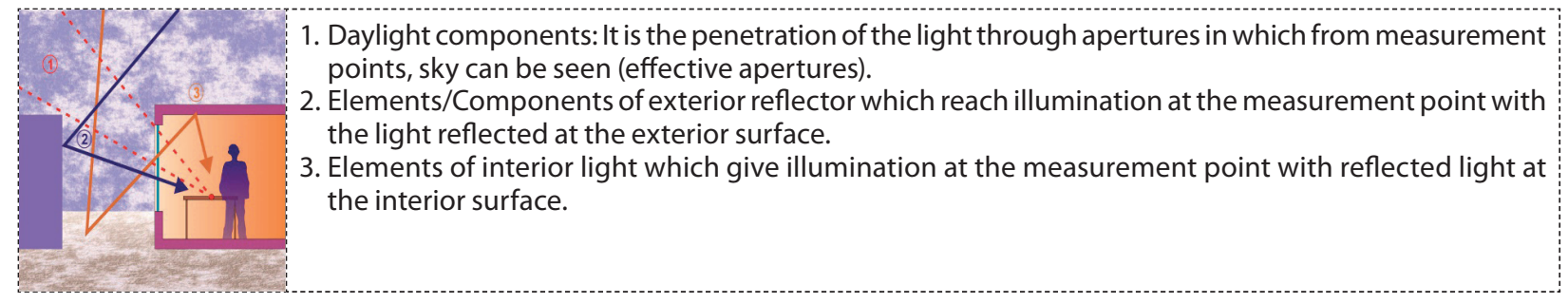

Fig. 3. 3 Daylight factor components

Source: Gretz 2002.

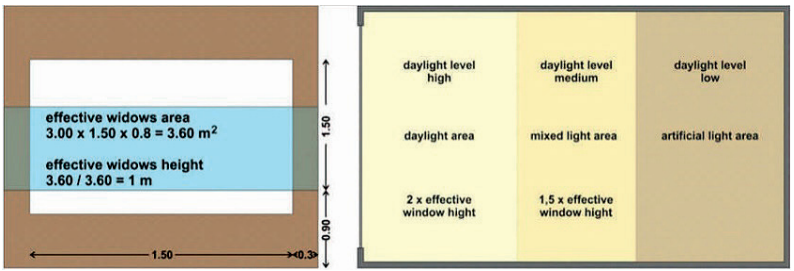

Fig. 4. Dimming and lighting level area

Source: Huddleston 2012.

area from the window, natural light will reduce, so in this area, artificial lighting is needed in daylight (Fig. 4 Right):

a. Daylight area. Daylight area with high level of natural lighting. This area starts from inner façade and has depth twice as double effective window's height. Generally, this area will have enough exposure of natural light that makes people can do normal activity.

b. Mixed Light Area. It is an area with medium natural lighting level. This area will need some additional artificial lighting to get satisfactory lighting level for normal activity throughout the day (the depth is about 1.5 of the effective window's height).

c. Artificial light area. It is an area with the low natural lighting level. This area must use artificial light to support the activity because it does not have enough natural lighting.

In connection with what have been mentioned above, Szokolay, stated that the use of artificial lighting during the day is frequent because there is lack of intensity of natural light and there is a need of visual contact with outside area.

For all these reasons, the principles of permanent supplementary artificial light of the interior (PSALI) has been defined as:

a. The use of natural light as much as possible;

b. The use of electric lighting to support natural lighting in the interior rooms;

c. Lighting design in such a way that it can maintain the natural lighting's basic character in the room.
Illumination provided by additional lighting must be proportional with the amount of daylight available near the window, at the contours DF $2 \%$.

The amount of the artificial light can be estimated as follows:

a. Determining daylight zone, either it serves as contour DF $2 \%$ or it takes DF as much as 0.2 $\mathrm{H}$ of the distance from the window and it is multiplied by 0.1 ( $\mathrm{H}$ is the height of an aperture measured from field work);

b. Find the $\mathrm{DF}_{\text {av }}$ average for the rest of the room;

c. Lighting that will be added to this area is

$\mathrm{E}_{\mathrm{add}}=500 \times \mathrm{DF}$.

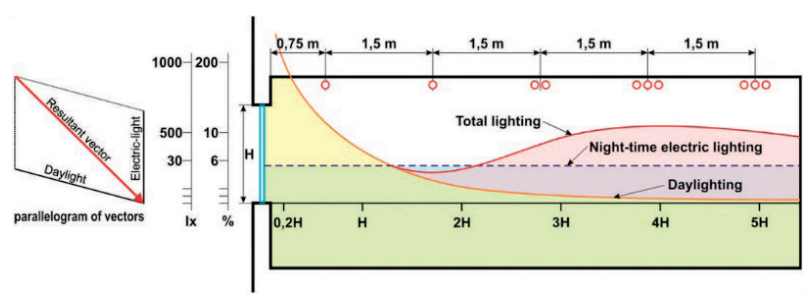

Fig. 5. Diagram of practical application of natural daylight and artificial light combination

Source: Szokolay 2008.

Figure 5 shows the equipment of electric lighting in the form of horizontal curtain five rows. In tropical area, it will lead a problem due to the solar heat radiation coming into the room, and it will eventually increase the load of air conditioner. Therefore, shading device is commonly used in tropical area to prevent heat which enters the building.

However, it is commonly found that buildings in tropical area often use shading system with excessive shading device (the designer may play safely). On the contrary, this condition is as bad as the condition in which shading device is inadequate (too small). With the excessive shading device, the room will be too dark and the artificial lighting (electricity) must be on all day in the room. It is not only wasting of energy but it is also significant increase of thermal loads due to the heat caused by the artificial lighting system. 
Unfortunately, the designer's lack of understanding and knowledge is often used as an excuse while sustainable architecture related to the energy conservation efforts will demand precise solar control system. The designer must be able to measure all the things to achieve the balance. It needs experiences to develop an instinct elated to how big this factor and to assistance in making qualitative argument without using complicated research and calculation in every design.

\section{Natural light control strategies}

One of the efforts to utilize natural light has been done through daylighting strategy in ancient building. Mintorogo (2004) in SunWord and Process Architecture, and Szokolay stated that generally daylighting strategies widely applied in passive design are classic daylighting in the form of Light-shelf. This strategy relies on reflector field to receive natural light (Fig. 6).

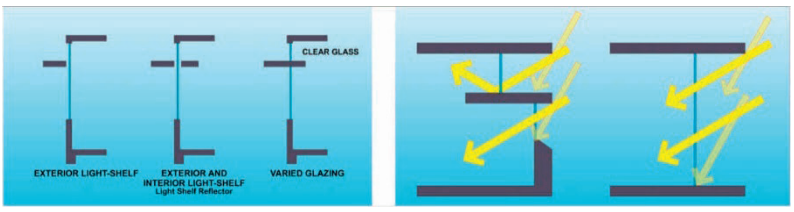

Fig. 6. The various forms of light shelf Source: Mintorogo 2004.
(Kido, Shiraishi 2013) research result dealing with light shelf revealed that, the light shelf improves the illumination by the side of the window and the illumination changes are moderated on the inside. Indoor lighting increases overall in winter, an area of over illumination distribution is also widespread. Therefore, the summer lighting environment is more consistent than other seasons.

Cunningham et al. (2014) explained that light shelf is a reflective device having flat, curved, horizontal or slightly angled form.

Research result (Hossein Moazzeni, Ghiabaklou 2016) dealing with light shelf in educational area of Tehran revealed that light shelf can reduce glare that very visually inconvenient. During the day, the result shows that light shelf can efficiently distribute daylight and increase visual comfort.

Kurtay, Esen (2016) conducted a research to determine the intensity of daylight between 300lx 500lx on the various placement and size of the light shelf (Fig. 9) at 6 latitude $\left(0^{\circ}, 15^{\circ}, 30^{\circ}, 45^{\circ}, 60^{\circ}, 75^{\circ}\right)$.

Light shelf researches, related to daylight distribution which has been done generally, are single light shelf while this research aims to determine the impact of using multiple light shelves on the natural light distribution and the room temperature.

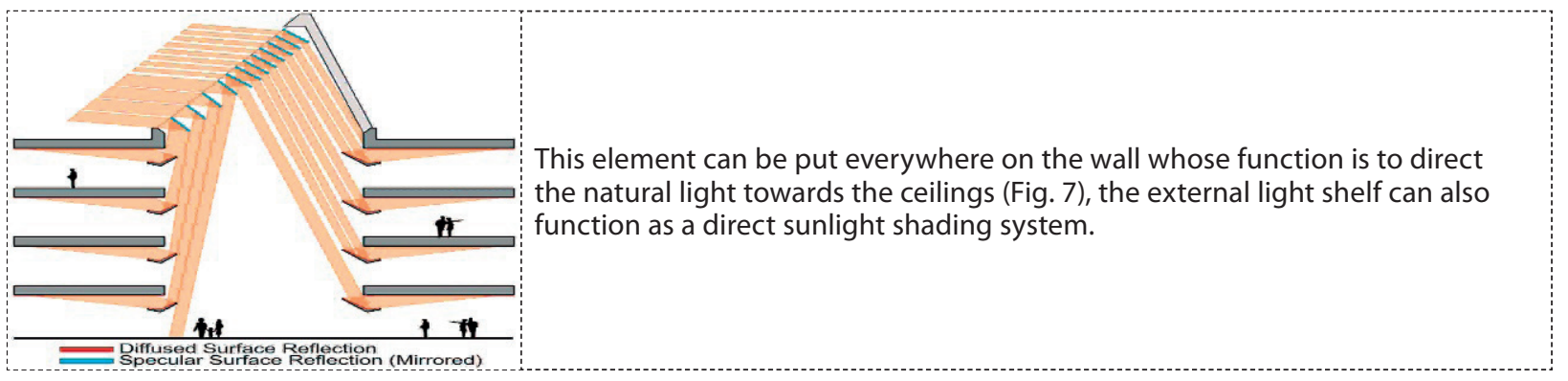

Fig. 7. Various forms of internal light shelf

Source: Cunningham et al. 2014.

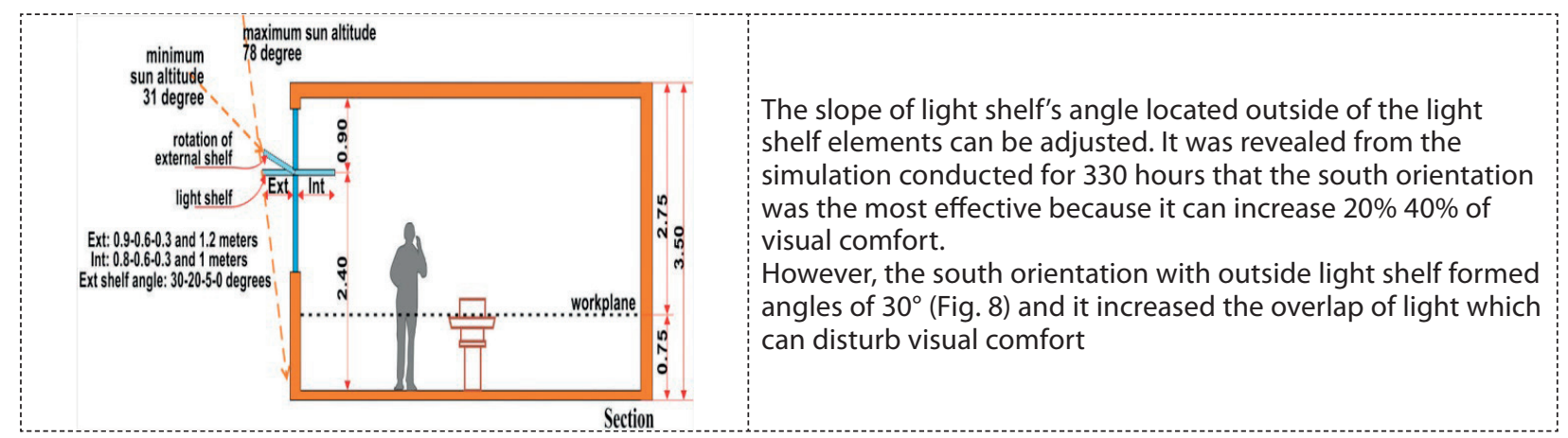

Fig. 8. Daylighting utilization strategy

Source: Hossein Moazzeni, Ghiabaklou 2016. 

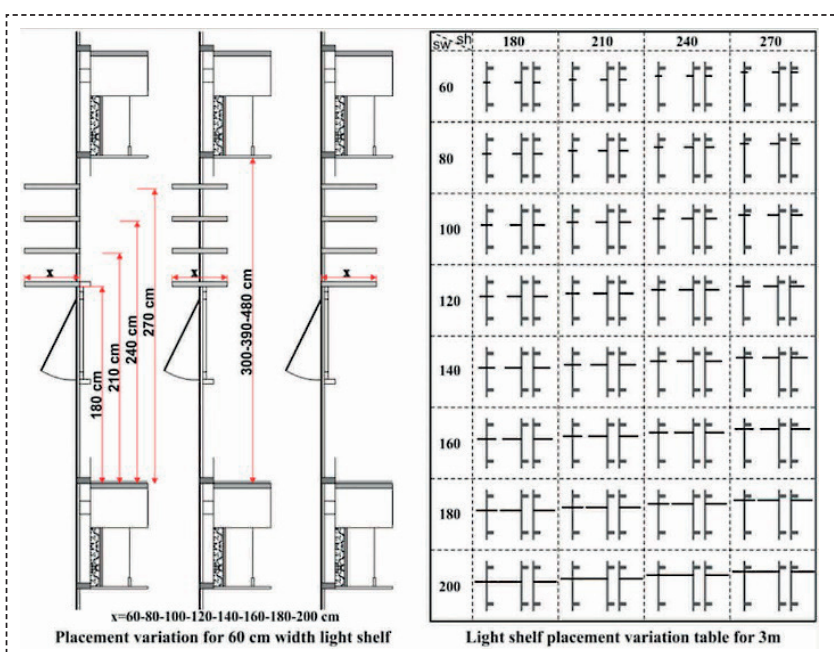

The result was simulated between two conditions; both with the light shelf and without light shelf. Kurtay's research result showed that the influence of light shelf on the distribution of daylight for office design could be considered different for each latitude position. At the latitude $0^{\circ} \& 15^{\circ}$, generally the efficiency of light shelf decreased for rising platform position, and at the latitude $30^{\circ}, 45^{\circ}, 60^{\circ}$ and $75^{\circ}$, the higher platform position, the more efficient the light shelf.

The suggestion for the use of light shelf at each latitude position is that it should use 3 meters ceilings because all light shelf's grade of efficiency is above $5 \%$.

Fig. 9. Variation of light shelf width and position Source: Kurtay, Esen 2016.

\section{Discussion}

\section{The result of natural light simulation comparison}

Figure 10 shows the comparison of natural light intensity at 7:00 a.m. It was seen that light the light without light shelf at MP1 2500 Lux (glaring) was much higher than natural light intensity with light shelf at MP1 1250 Lux. In general, light intensity toward MP 6 decreased because it avoided apetures. Although the intensity of the deepest part (MP6) is less qualified for working room, about $200 \mathrm{Lux}$, with $150 \mathrm{Lux}$, it is still possible for reading and writing activities in general.
Figure 11 shows the comparison natural light intensity in the morning at 9:00 a.m. It was seen that the light intensity without light shelf near apertures is very high and glaring (MP1 = $3200 \mathrm{Lux})$; while natural light intensity with multiple light shelves was seen more evenly distributed (MP1 = $1050 \mathrm{Lux})$, and the deepest part intensity (MP6) is still qualify for working rooms which was approximately 200 Lux

Figure 12 shows the comparison of natural light intensity at $12 \mathrm{a} . \mathrm{m}$. It was seen that light intensity without light-shelf near apertures (MP1 $=3000$ Lux) was still high and glaring, and the intensity of the deepest part

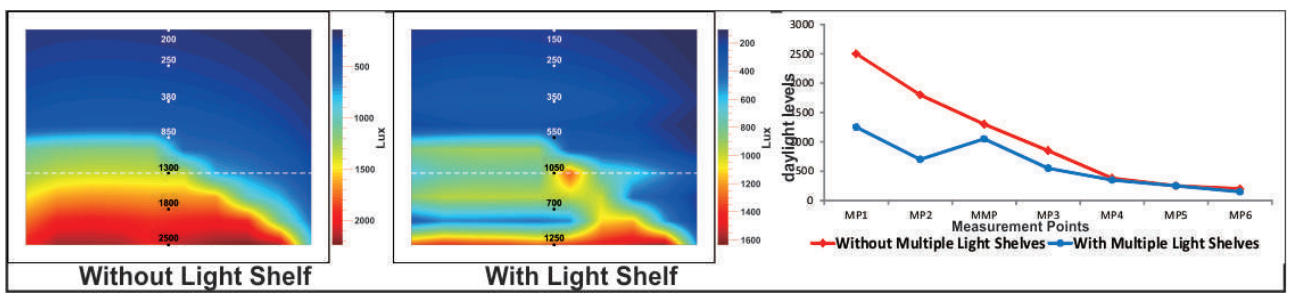

Fig. 10. Comparison of light distribution at 7 a.m.

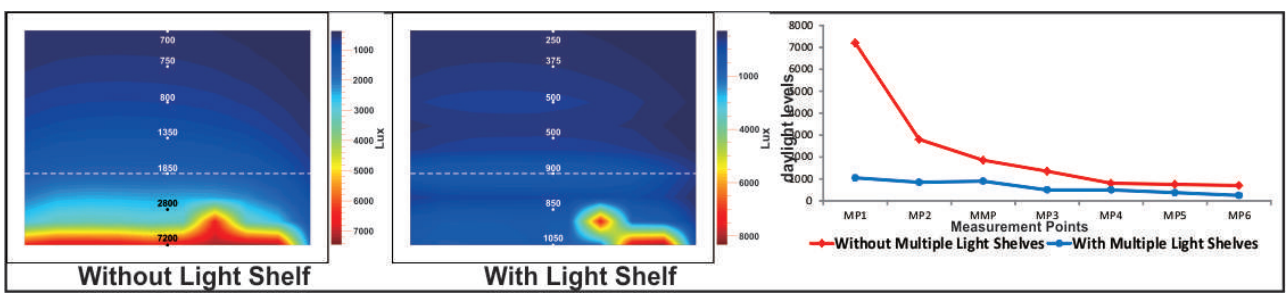

Fig. 11. Comparison of light distribution at 9 a.m.

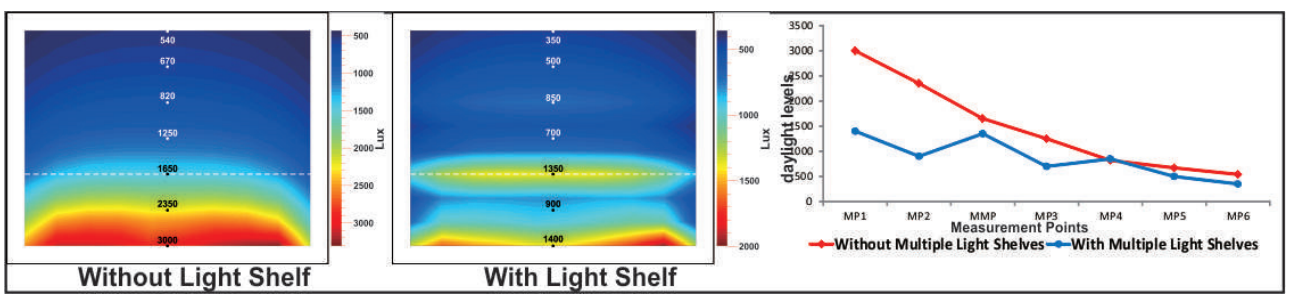

Fig. 12. Comparison of light distribution at 12 a.m. 
(MP6 = 540 Lux) was still too high for reading and writing activities; while the natural light intensity with multiple light shelves was seen more evenly distributed $(\mathrm{MP1}=1400 \mathrm{Lux})$, and the intensity of the deepest part $(\mathrm{MP6}=350 \mathrm{Lux})$ is not too high for the working rooms which was about 200 Lux.

Figure 13 shows the comparison of natural light intensity at $3 \mathrm{p}$.m. It was seen that light intensity near apertures without light-shelf (MP1 = 1800 Lux) is still too high and too glaring, and the intensity of deepest part (MP6 $=350$ Lux) is too high for reading and writing activities. Furthermore, the natural light intensity with multiple light shelves was seen more evenly distributed at MP1 $=910$ Lux, and the intensity of deepest part (MP6 $=330 \mathrm{Lux})$ is not too glaring for the working rooms which was about 200 Lux.

Figure 14 shows the comparison of natural light intensity at 3 p.m. It was seen that light intensity without light-shelf near apertures $(\mathrm{MP1}=925 \mathrm{Lux})$ was too high and glaring, the intensity of the deepest part (MP6 = 120 Lux) was low enough for reading and writing activities. The natural light intensity with multiple light shelves was seen more evenly distributed $(\mathrm{MP1}=460 \mathrm{Lux})$ although the intensity of the deepest part (MP6 = 120 Lux) was low enough for reading and writing activity and it was almost similar to the one without light-shelf for working rooms (around 200 Lux).

Figure 15 shows the comparison of average natural light intensity during a day.

The result of comparison of light intensity between with light shelf and without light shelf mentioned above has shown us that the use of multiple light shelves can reduce excessive light intensity especially the one near the apertures. On the other hand, in the inside part far from apertures, the light intensity was relatively similar. In other words, the use of multiple light shelves is one of the strategies to distribute natural light equally.

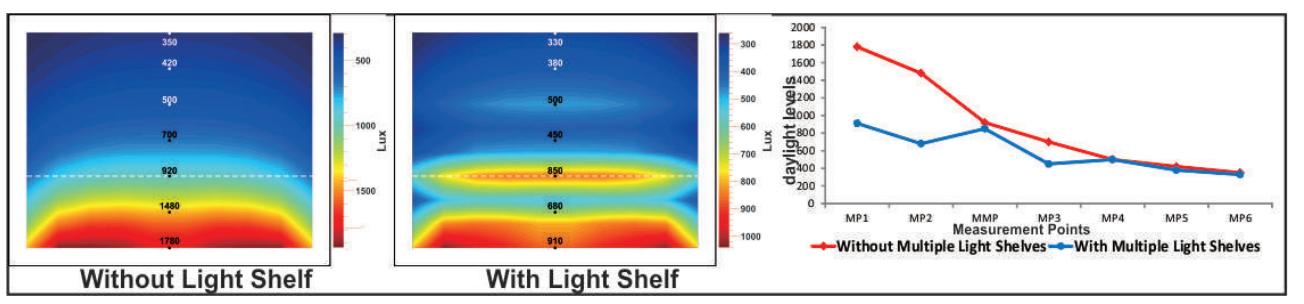

Fig. 13. Comparison of light distribution at 3 p.m.

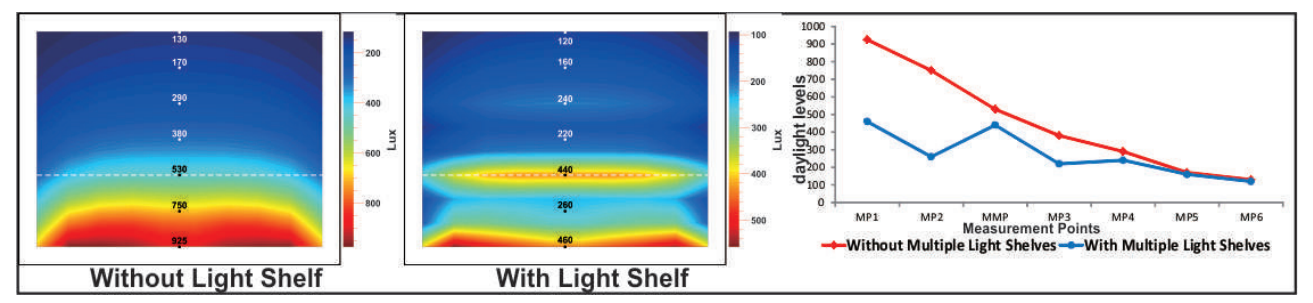

Fig. 14. Comparison of light distribution at 5 p.m.

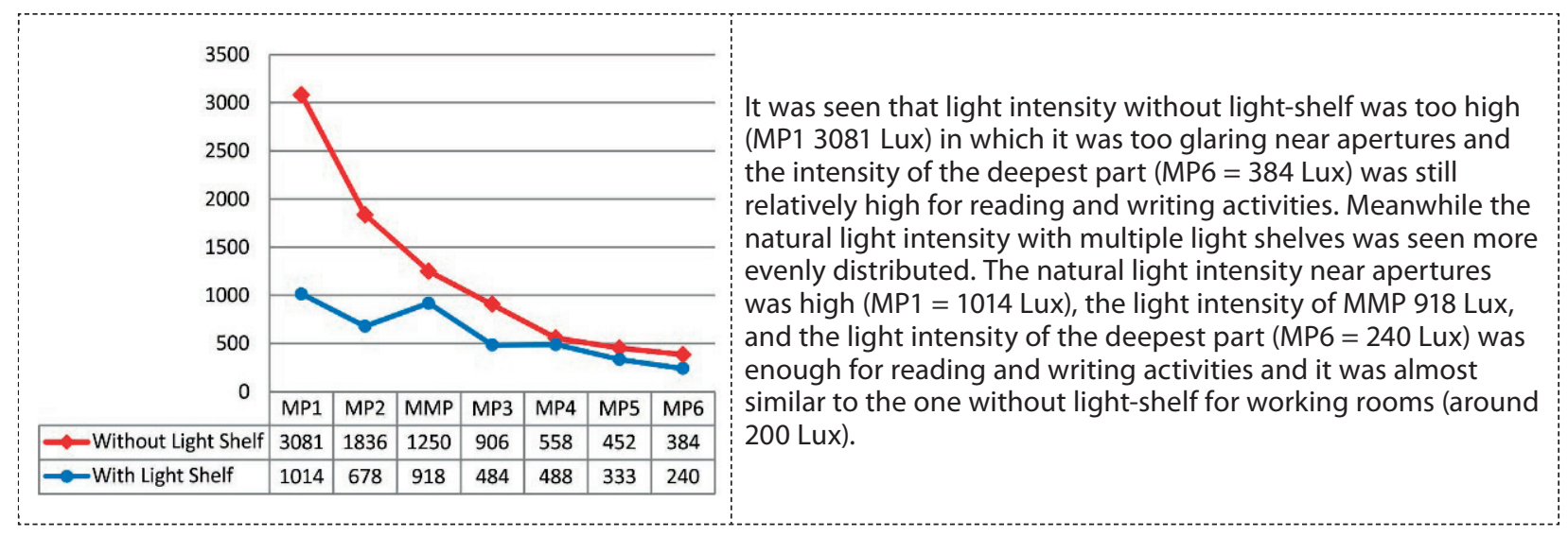

Fig. 15. Comparison of average natural light intensity during a day 
Table 1. The Comparison of the effective air temperature average

\begin{tabular}{|l|c|c|c|c|c|}
\hline \multicolumn{1}{|c|}{} & \multicolumn{4}{|c|}{ Effective Temperature on Period of Time } \\
\hline Without Multiple Light shelves & 7.00 & 9.00 & 12.00 & 15.00 & 17.00 \\
\hline With Multiple Light shelves & $22.7^{\circ} \mathrm{C}$ & $26.2^{\circ} \mathrm{C}$ & $27.9^{\circ} \mathrm{C}$ & $29.1^{\circ} \mathrm{C}$ & $28.7^{\circ} \mathrm{C}$ \\
\hline
\end{tabular}

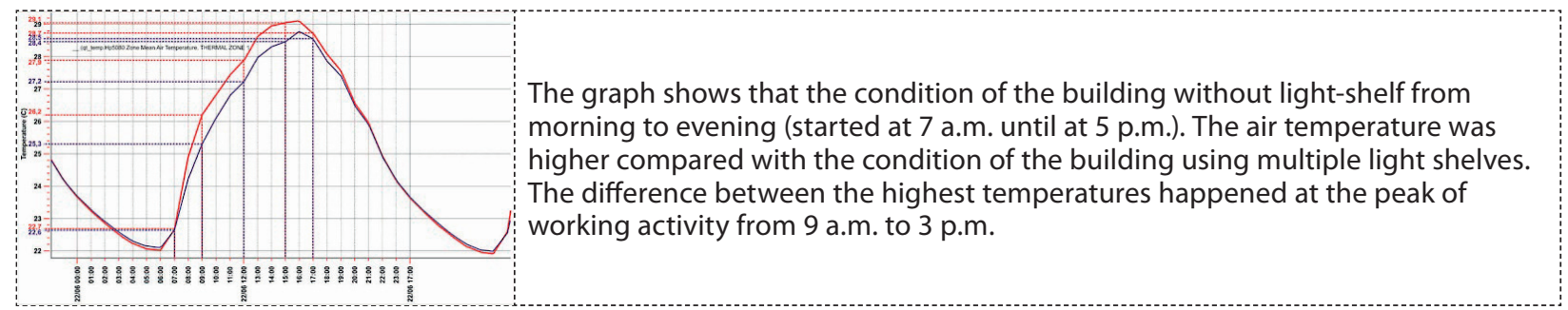

Fig. 16. The graph of the average air effective temperature comparison

\section{The comparison of the effective air temperature average from simulation results}

The comparison of the air effective temperature average between the building condition without light-shelf and with multiple light shelves during a day can be seen in Figure 16. It shows the graph of the effective temperature average while Table 1 shows the effective temperature average at 7 a.m., 9 a.m., 12 a.m., 3 p.m., and 5 p.m.

\section{Conclusions}

\section{Light Intensity}

The influence of using light-shelf on the distribution of natural light is very significant, as:

1.1. For the building which do not use light-shelf, the natural light intensity is not equally distributed, and the natural light intensity is too high near apertures and drastically decreases inward avoiding apertures.

1.2. The natural lighting intensity that is too high can cause: a) glare which can disturb sight, b) eye muscles to contract pupils that eventually fatigue eyes fast, and c) problems of sight while doing activity.

\section{The Average Room Temperature}

The use of light-shelf is also intended as an effort to prevent direct sunlight that makes the room temperature high. The influence of using light-shelf on average temperature in a room is also very significant. The comparison between building without light-shelf and building with light-shelf are: from morning until evening (starting at 7 a.m. until at 9 p.m.), the temperature of the building without light-shelf was higher than the building with light-shelf. The difference between the highest temperatures happened at the peak hours of working activities, between 9 a.m. until 3 p.m., and it certainly significantly influenced the energy load of air conditioners.

\section{Acknowledgements}

I feel grateful that this journal has been completed and I thank to everyone for their contributions especially to Mr. Jalal Er Riyanto who has helped and supported me to complete this research.

\section{References}

Cunningham, P.; Zaferiou, P.; Lagios, 2014. A case study in reflective daylighting, Perkins+Will Research Journal 06.01.

Egan, M. D. 1983. Concept in architectural lighting. McGrawHill Book Company.

Gretz, W. 2002. Sustainable design guide-the building architectural design. Laboratory Implementation Requirements Chapter 4. LANL (Los Alamos National Laboratory), New Mexico.

Heinz, F. 2008. Ilmu Fisika Bangunan-Pengantar pemahaman cahaya, kalor, kelembaban, iklim, gempa bumi, bunyi \& kebakaran. Yogyakarta: Penerbit Kanisius.

Hossein Moazzeni, M.; Ghiabaklou, Z. 2016. Investigating the influence of light shelf geometry parameters on daylight performance and visual comfort, a case study of educational Spacein Tehran, Iran. Multidisciplinary Digital Publishing Institute MDPI, Basel, Switzerland.

Huddleston, N. 2012. Climate change-evidence, impact, and choices. USA: National Oceanic and Atmospheric Administration (NOAA).

Kido, H.; Shiraishi, Y. 2013. Characteristics of indoor lighting environment using daylight with a light shelf, International Journal of Environmental Science and Development 4(6).

Kurtay, C.; Esen, O. 2016. The Efficiency of light shelves according to latitudes in office buildings, Gazi University Journal of Science 29(4): 711-721.

Liebard, A.; de Herde, A. 2004. Bioclimatic facades. Somfy SAS.

Mintorogo, D. S. 2004. The 3 - in - 1 skylight shading device for Surabaya Indonesia. An energy saving and considerations. Surabaya: Dimensi Teknik Arsitektur, Des, Vol. 32, p. 150. 
Rüdiger, G.; Hofmann, H. 1992. Handbook of lighting design. Berlin: Druckhaus Maack. Lüdenscheid OffsetReproTechnik.

Smith, P. F. 2005. Architecture in a climate of change. Oxford. Jordan Hill: Elsevier Ltd, Linacre House.

Steffy, G. 2002. Architectural lighting design. New York: John Willey \& Sons, Inc.

Szokolay, S. V. 2008. Introduction to architectural sciencethe basis of sustainable design. Jordan Hill, Oxford: Architectural Press is an imprint of Elsevier Linacre House.

\section{EDDY INDARTO}

As a lecturer with scientific concentration in the field of Green Building in the Department of Architecture, Faculty of Engineering, Diponegoro University, Semarang, Indonesia.

\section{GAGOEK HARDIMAN}

As a lecturer and professor with scientific concentration in Building Physics at Department of Architecture, Faculty of Engineering, Diponegoro University, Semarang, Indonesia.

\section{WAHYU SETIA BUDI}

As a lecturer and professor with scientific concentration in the field of Medical Physics at the Department of Physics, Faculty of Mathematics and Science, Diponegoro University, Semarang, Indonesia.

\section{DJALAL ER RIYANTO}

As a lecturer with scientific concentration in the field of information technology in the Department of Physics, Faculty of Mathematics and Science, Diponegoro University, Semarang, Indonesia. 